\title{
Hydroxyurea nitrosylates and activates soluble guanylyl cyclase in human erythroid cells
}

\author{
Vladan P. Cokic, ${ }^{1}$ Silvana A. Andric, ${ }^{2}$ Stanko S. Stojilkovic, ${ }^{2}$ Constance T. Noguchi, ${ }^{3}$ and Alan N. Schechter ${ }^{3}$ \\ ${ }^{1}$ Laboratory of Experimental Hematology, Institute for Medical Research, Belgrade, Serbia; ${ }^{2}$ Section on Cellular Signaling, National Institute of Child Health and \\ Human Development, National Institutes of Health (NIH), Bethesda, MD; ${ }^{3}$ Molecular Medicine Branch, National Institute of Diabetes and Digestive and Kidney \\ Diseases, NIH, Bethesda, MD
}

\begin{abstract}
Hydroxyurea, a drug widely used for treating myeloproliferative diseases, has also been approved for the treatment of sickle cell disease by raising fetal hemoglobin (HbF). We have shown that nitric oxide (NO) and the soluble guanylyl cyclase (sGC) pathways are involved in hydroxyurea induction of HbF levels in erythroid progenitor cells (EPCs). We demonstrate now that during erythroid differentiation, endothelial NO synthase mRNA and protein levels decline steadily, as does the production of NO derivatives and cyclic
\end{abstract}

adenosine monophosphate (cAMP) levels, but guanosine $3^{\prime}, 5^{\prime}$-cyclic monophosphate (cGMP) levels are stable. Hydroxyurea increased intracellular cGMP levels and cAMP levels in EPCs. The NO donor, DEANONOate, induced much higher cGMP levels, but reduced cAMP levels. Hydroxyurea $(1 \mathrm{mM})$ induced production of approximately 45 pM cGMP/minute/ng of purified SGC, similar to induction by $1 \mu \mathrm{M}$ DEANONOate. We found that hydroxyurea and ProliNONOate produced iron-nitrosyl derivatives of sGC. Thus, we confirm that hydroxyurea can directly interact with the deoxy-heme of SGC, presumably by a free-radical nitroxide pathway, and activate cGMP production. These data add to an expanding appreciation of the role of hydroxyurea as an inducer of the NO/cGMP pathway in EPCs. These mechanisms may also be involved in the cytostatic effects of hydroxyurea, as well as the induction of HbF. (Blood. 2008;111: 1117-1123)

두 2008 by The American Society of Hematology

\section{Introduction}

Hydroxyurea is a cytostatic drug that has been used to treat a variety of myeloproliferative diseases but has recently been shown to be effective in elevating fetal hemoglobin $(\mathrm{HbF})$ as a therapy for individuals with sickle cell disease. ${ }^{1,2}$ An intracellular signaling pathway including soluble guanylyl cyclase (sGC) and guanosine $3^{\prime}, 5^{\prime}$-cyclic monophosphate (cGMP)-dependent protein kinase $(\mathrm{PKG})$ was reported to induce the expression of the gamma-globin gene (HBG1) of $\mathrm{HbF}$ in human erythroid cell lines and primary cells. ${ }^{3}$ We demonstrated that hydroxyurea effects include the nitric oxide (NO)-dependent activation of sGC in cultured $\mathrm{CD} 4^{+}$human erythroid precursor cells. ${ }^{4}$ Hydroxyurea has been reported to significantly increase NO and cGMP in the blood of patients with sickle cell anemia. ${ }^{5}$ In addition, cGMP levels were found to be significantly higher in the red blood cells (RBCs) of patients with sickle cell anemia than those of healthy individuals, and were further increased in RBCs of patients with sickle cell anemia on hydroxyurea therapy. ${ }^{6}$ The cyclic adenosine monophosphate (cAMP)-dependent pathway, which is independent of the mitogen-activated protein kinase (MAPK) pathways, appears to play a negative role in gamma-globin gene expression in K562 erythroleukemia cells. ${ }^{7}$

It is established that hydroxyurea inhibits ribonucleoside diphosphate reductase, thereby blocking DNA synthesis and repair. ${ }^{8}$ Hydroxyurea is converted to a free radical nitroxide in vivo and transported by diffusion into cells, where it quenches the tyrosyl free radical at the active site of ribonucleotide reductase, inactivat- ing the enzyme. ${ }^{9}$ Transient nitroxide-like radicals from hydroxyurea have been detected in the reaction of hydroxyurea with protein R2 from Escherichia coli and mouse, indicating that 1-electron transfer from hydroxyurea to the tyrosyl radical is the dominating mechanism in the inhibitor reaction. ${ }^{10}$ An electron spin resonance spectroscopic study also demonstrated that NO was generated from hydroxyurea. ${ }^{11}$ Both NO gas and NO generated by activated macrophage lysates inhibit tumor cell ribonucleotide reductase. ${ }^{12}$ Cytostasis by activated macrophages and by hydroxyurea appears to have comparable mechanisms, including, but probably not limited to, inhibition of ribonucleotide reductase. ${ }^{13}$ These results suggest that NO production from hydroxyurea may be the molecular basis of the pharmacologic and antitumor activity of hydroxyurea. ${ }^{14}$

To define the relationship between hydroxyurea stimulation of erythroid progenitor cells to increase $\mathrm{HbF}$ and NO pathways, we investigated the NO production and NO synthase expression during erythroid differentiation. Hydroxyurea elevated intracellular cGMP and cAMP levels of human erythroid progenitor cells. Using purified sGC in solution with GTP, as substrate, we found that hydroxyurea induced production of cGMP. We also measured the formation of the iron-nitrosyl complex as the end product of the reaction of hydroxyurea and the heme of sGC. These results help in elucidate the hydroxyurea role in sGC induction as well as providing a mechanism by which hydroxyurea may generate bioactive NO.
Submitted May 21, 2007; accepted October 30, 2007. Prepublished online as Blood First Edition paper, November 9, 2007; DOI 10.1182/blood-200705-088732.

The publication costs of this article were defrayed in part by page charge payment. Therefore, and solely to indicate this fact, this article is hereby marked "advertisement" in accordance with 18 USC section 1734. 


\section{Methods}

\section{The 2-phase liquid erythroid cell cultures}

Peripheral blood mononuclear cells were isolated from buffy coats of healthy donors. We performed a 2-phase liquid culture protocol previously described. ${ }^{4}$ Briefly, after incubation in phase I culture in the absence of erythropoietin, $\mathrm{CD} 34^{+}$cells were harvested by centrifugation and purified by negative selection using the StemSep Cell Separation method (Stem Cell Technologies, Vancouver, BC). The CD $34^{+}$cells were resuspended in the phase II medium, which contained a mixture of cytokines, including human recombinant erythropoietin (Amgen, Thousand Oaks, CA). The concentration of total proteins and hemoglobins in erythroid cells plated in wells of a 96-well microplate $\left(1 \times 10^{5}\right.$ cells/well $)$ were assessed using an 8453 UV/Visible Spectrophotometer (Hewlett-Packard, Waldbronn, Germany). Cells were subsequently cultured for 16 hours in $200 \mu \mathrm{L}$ of fresh medium containing an appropriate concentration of bradykinin (Alexis Biochemicals, San Diego, CA). The activated cells in wells were washed twice with Dulbecco phosphate-buffered saline (PBS; Invitrogen, Carlsbad, CA), and then $10 \mu \mathrm{M}$ diaminofluorescein (DAF-2; Alexis Biochemicals) and $1 \mathrm{mM}$ 1-arginine (Sigma, St Louis, MO) were added. After incubation for a further 2 hours, the supernatants (an aliquot of $10 \mu \mathrm{L}$ of each cell supernatant) were transferred to black microplates, and the fluorescence of NO/DAF-2 interaction was measured with a fluorescence microplate reader calibrated for excitation at $485 \mathrm{~nm}$ and emission at $538 \mathrm{~nm}$.

\section{Isolation of total RNA}

For isolation of total RNA from erythroid cells we used the RNeasy procedure (Qiagen, Valencia, CA) according to the manufacturer's instructions. The concentration and integrity of total RNA were assessed using an 8453 UV/Visible Spectrophotometer (Hewlett-Packard) and Agilent 2100 Bioanalyzer (Agilent Technologies, Waldbronn, Germany). A total of $1 \mu \mathrm{g}$ of total RNA was reverse transcribed with SuperScript II RNase $\mathrm{H}^{-}$ Reverse Transcriptase kit (Invitrogen).

\section{Quantitative PCR}

Quantitative real-time polymerase chain reaction (PCR) assay of human inducible NO synthase (iNOS) mRNA transcripts was carried out with the use of gene-specific double-fluorescently labeled probe (5'-CAA GAG CCA GAA GCG CTA TCA CGA AGA T-3') in a 7700 Sequence Detector (Applied Biosystems, Foster City, CA). The specific primers of iNOS (sense: 5'-AGG TCG AGG ACT ATT TCT TTC AGC-3'; antisense: 5'-CTG TCC TTC TTC GCC TCG TAA G-3') and TAQMAN probes (synthesized by the National Institute of Diabetes and Digestive and Kidney Diseases [NIDDK] core oligonucleotide facility) were designed using Primer Express software and prepared on an ABI 394 synthesizer (both from Applied Biosystems). The specific primers of human endothelial NO synthase (eNOS) mRNA transcript and TAQMAN probe were designed as previously described. ${ }^{15}$ Platinum Quantitative PCR SuperMix-UDG (Invitrogen) was used, containing a final concentration of $200 \mu \mathrm{M} 2^{\prime}$ deoxynucleoside $5^{\prime}$-triphosphates (dNTPs is a mix of dATP, dCTP, dGTP, and dTTP), $0.5 \mu \mathrm{M}$ Rox reference dye (Invitrogen), $0.2 \mu \mathrm{M}$ each of TAQMAN probe, sense, and antisense primers. Expression levels were determined using the associated SDS software (ABI Prism; Applied Biosystems) and Microsoft Excel (Redmond, WA).

\section{Ozone-based chemiluminescent determination of nitrite in supernatant of cell culture}

For nitrite $\left(\mathrm{NO}_{2}{ }^{-}\right)$and total $\mathrm{NO}$ (nitrate plus nitrite plus nitrosothiols equals NOx) measurements in supernatant of erythroid cell cultures, erythroleukemic and erythroid cells in 6-well plates were washed once with Dulbecco PBS. After 2 hours, the supernatant was immediately frozen on dry ice and stored at $-80^{\circ} \mathrm{C}$. $\mathrm{NO}_{2}{ }^{-}$is measured as already described, ${ }^{16}$ whereas NOx was measured using vanadium (III) chloride in hydrochloric acid at $90^{\circ} \mathrm{C}$ with the Sievers Model 280 NO analyser (Sievers, Boulder, CO). Helium was bubbled through the reaction mixture. $\mathrm{I}_{3}{ }^{-}$-based chemiluminescence assay was modified with acidified sulfanilamide and $\mathrm{HgCl}_{2}$ as follows: purified sGC (300-350 nM, diluted in PBS without $\mathrm{Ca}^{2+}$ and $\mathrm{Mg}^{2+}$ ) was treated with hydroxyurea and ProliNONOate $\left(\mathrm{t}_{1 / 2}=1.8\right.$ seconds at $37^{\circ} \mathrm{C}$, $2 \mathrm{M}$ of $\mathrm{NO}$ released per mole of NO donor; Alexis Biochemicals) for an incubation time of 10 minutes at $37^{\circ} \mathrm{C}$. Samples were transferred on dry ice for freezing. For analysis, samples were thawed at room temperature and acidified sulfanilamide was quickly added (final concentration, $0.5 \%$ ) as well as $\mathrm{HgCl}_{2}$ (final concentration, $5 \mathrm{mM}$ ). Acidified sulfanilamide reacts with nitrite to form a diazonium compound that is not reduced to $\mathrm{NO}$ in the $\mathrm{I}_{3}$ chemiluminescent assay (and consequently does not have a signal). NO concentrations from the samples containing acidified sulfanilamide and $\mathrm{HgCl}_{2}$ represent plasma iron-nitrosyl levels only. ${ }^{17}$ After 2 minutes, samples were transferred on wet ice and measured with $\mathrm{NO}$ analyzer.

\section{Immunoblotting}

Cell lysates were heated to $90^{\circ} \mathrm{C}$ for 10 minutes in LDS sample buffer (Invitrogen). Proteins were then separated on 3\% to 8\% NuPAGE Tris acetate gels and transferred onto polyvinylidene difluoride membranes (Invitrogen), and then probed in immunoblots using eNOS (BD Transduction Laboratories, San Jose, CA) and actin (Santa Cruz Biotechnology, Santa Cruz, CA) monoclonal antibodies according to the protocols provided by the suppliers. The membrane was incubated with a primary antibody overnight at $4^{\circ} \mathrm{C}$, and afterward 1 hour at room temperature with a horseradish peroxidase-conjugated sheep anti-mouse IgG. Proteins were visualized by chemiluminescence (ECL plus; Amersham Biosciences, Piscataway, NJ). The intensities of immunoreactive bands in Western blots were analyzed by using the NIH IMAGE program (FluorChem Imaging system; Alpha Innotech, San Leandro, CA).

\section{High-performance liquid chromatography}

Erythroid cells were harvested at different time points during erythroid differentiation. To perform high-performance liquid chromatography (HPLC) quantitation of hemoglobin, we separated hemoglobins by cation exchange HPLC of supernatants from cell lysates. The pelleted cells were resuspended, lysed in sterile distilled water, and centrifuged in $0.45 \mu \mathrm{m}$ filter unit (Millipore, Bedford, MA) for 10 minutes at $4^{\circ} \mathrm{C}$. The filtrate was chromatographed on a PolyCAT A $20 \times 4.0 \mathrm{~mm}$ column (PolyLC, Columbia, MD) fitted to a Gilson HPLC system (Gilson, Middleton, WI) developed with a sodium acetate gradient in $20 \mathrm{mM}$ BisTris buffer $(\mathrm{pH}$ 6.55-6.96). Peak areas were integrated with the use of the system software.

\section{Human eNOS immunoassay}

Erythroid cells were washed 2 times in PBS, the supernate was discarded, and the cells were lysed at $4^{\circ} \mathrm{C}$ with cell lysis buffer (R\&D Systems, Minneapolis, MN), $1 \mathrm{~mL}$ of buffer per $1 \times 10^{6}$ cells. The cells were centrifuged at $300 \mathrm{~g}$ for 5 minutes, and the supernate was removed and assayed immediately or aliquoted and stored at $-20^{\circ} \mathrm{C}$ or less for up to 24 hours. eNOS protein levels were measured using the human eNOS immunoassay (R\&D Systems) according to the protocol of the supplier.

\section{cGMP and cAMP measurements}

Erythroid progenitor cells were treated with hydroxyurea or DEANONOate (sodium(Z)-1-(N,N-diethylamino)diazen-1-ium-1,2-diolate; $\mathrm{t}_{1 / 2}=2$ minutes at $37^{\circ} \mathrm{C}, 1.5 \mathrm{M}$ of $\mathrm{NO}$ released per mole of $\mathrm{NO}$ donor; Alexis Biochemicals) at day 4 of culture and about $1 \times 10^{6}$ cells were harvested at different time points. Cells were pretreated 30 minutes with 3-isobutyl-1-methylxanthine (Sigma) at a final concentration of $0.5 \mathrm{mM}$ to inhibit phosphodiesterase activity. Cyclic nucleotides were measured in cell extract by radioimmunoassay using specific antisera provided by Albert Baukal (National Institute of Child Health and Human Development [NICHD], Bethesda, MD). Mixtures of purified sGC (Alexis Biochemicals), $3 \mathrm{mM} \mathrm{MgCl}_{2}$ (cofactor), and $1 \mathrm{mM} \mathrm{GTP}$ (substrate) were treated with hydroxyurea and DEANONOate, and incubated for 10 minutes at $37^{\circ} \mathrm{C}$ (shaking on $600 \mathrm{rpm}$ ). After incubation, mixtures were diluted in $1 \mathrm{~mL}$ cold PBS $\left(\mathrm{pH}=7.4\right.$; without $\mathrm{Mg}^{2+}$ and $\mathrm{Ca}^{2+}$ ). A total of $10 \mu \mathrm{L}$ acidmix 
(two-thirds triethylamine and one-third acetic anhydride) was added to a $0.5-\mathrm{mL}$ mixture with sGC in glass tubes. After vortexing for 7 to 10 seconds, $0.1 \mathrm{~mL}$ of mixture was transferred in new glass tubes. Tubes were covered with Parafilm (American National Can Company, Chicago, IL) and frozen at $-80^{\circ} \mathrm{C}$ for storage and thawed before measurement by radioimmunoassay.

\section{Statistical analysis}

The 1-way analysis of variance (ANOVA) and Dunnett post tests were applied using Prism 4 software (GraphPad Software, San Diego, CA).

\section{Results}

NOS activity in erythroid cells during differentiation

After isolation of $\mathrm{CD}_{3}{ }^{+}$progenitor cells at day 0 (about $90 \%$ purity), erythroid differentiation was stimulated by a mixture of cytokines, including erythropoietin. We observed a fall in both $\mathrm{NO}_{2}{ }^{-}$and NOx levels during differentiation of erythroid cells (Figure 1A). An increase in NOx levels occurred at day 18, which paralleled the marked decrease in cell number and increased apoptosis of erythroid cells at this time. The levels of hemoglobin (primarily $\mathrm{HbA}$ ), a scavenger of $\mathrm{NO}$, were enriched during erythroid differentiation of $\mathrm{CD} 34^{+}$cells as expected (Figure 1B), as measured by spectrophotometry and HPLC. To show eNOS activity, we treated erythroid progenitor cells with the well-known eNOS inducer bradykinin. The dose-dependent induction of extracellular NO levels was observed during bradykinin treatment of erythroid cells as measured by the fluorescent indicator DAF-2 (Figure 1C). Induction of intracellular NO levels was also revealed during bradykinin treatment as measured by the fluorescent indicator DAF-2 diacetate (data not shown).

\section{NOS levels in erythroid cells during differentiation}

It has been reported that human RBCs express an active and functional eNOS, which is localized in the plasma membrane and the cytoplasm of RBCs. ${ }^{18}$ According to our experiments, the highest eNOS mRNA levels were detected in $\mathrm{CD} 34^{+}$progenitor cells at day 0 . After that, a prominent decline of eNOS mRNA levels in erythroid cells was observed, with a slight elevation at day 14 associated with the start of apoptosis (Figure 2A). Insignificant levels of iNOS mRNA was found during maturation of erythroid cells but with also an apparent slight increase at day 14 (Figure 2B). We did not detect nNOS mRNA and protein in erythroid cells (data not shown). A continuous fall of eNOS protein levels was demonstrated during the maturation of erythroid cells (Figure 2C,D). At day 14, eNOS protein is still detected in erythroid cell cultures by enzyme-linked immunosorbent assay (ELISA; Figure 2C) but no longer observed by the less-sensitive Western blotting technique (Figure 2D).

\section{Intracellular cyclic nucleotides levels in human erythroid progenitor cells}

We have previously shown that hydroxyurea and the NO donor CysNO $\left(\mathrm{t}_{1 / 2}=30\right.$ minutes $)$ increased cGMP levels in erythroid cells. ${ }^{4}$ Here, we use the cyclic nucleotide-specific radioimmunoassays to compare cGMP and cAMP production. We found a continuous fall in cAMP levels in contrast to steady levels of cGMP during erythroid differentiation (Figure $3 \mathrm{~A}$ ). The cGMP levels in erythroid progenitor cells were similar to primitive $\mathrm{CD} 34^{+}$progenitor cells, whereas both cGMP and cAMP levels were minor in

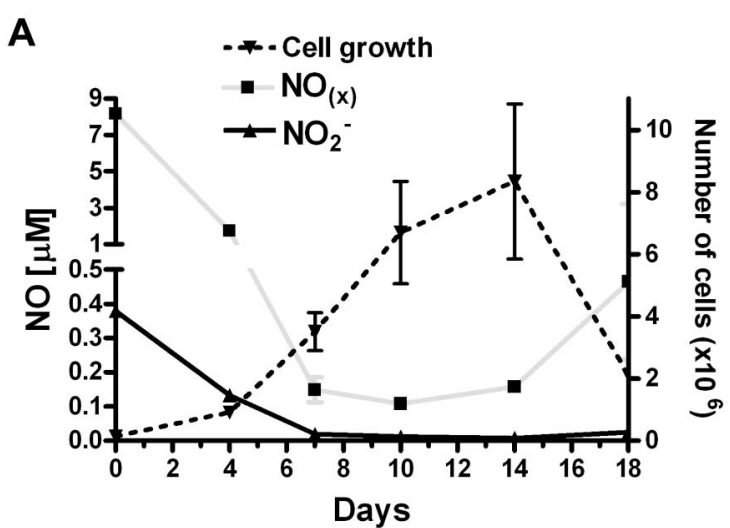

B
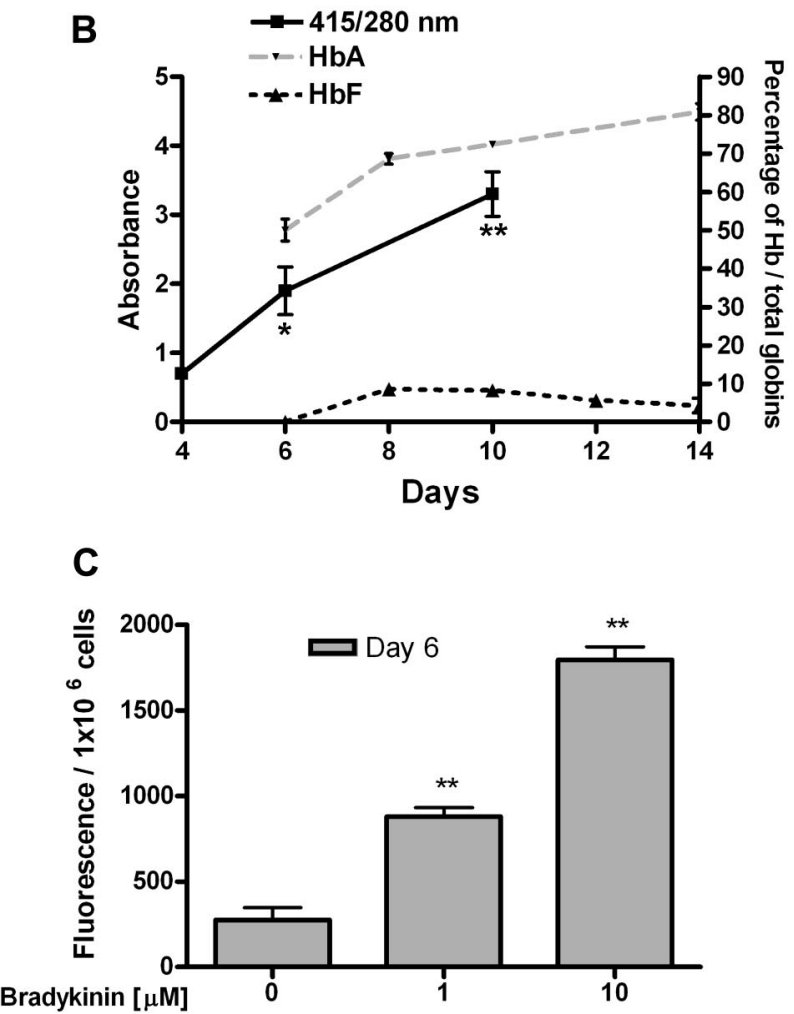

Figure 1. Characterization of 2-phase liquid culture of erythroid cells. (A) NO production during erythroid differentiation (per $1 \times 10^{6}$ cells; $n=3$ ). (B) Total globins per total protein levels during erythroid differentiation of $\mathrm{CD} 34^{+}$cells. The heme group of globins gives a maximum absorbance at $415 \mathrm{~nm}$, while $280 \mathrm{~nm}$ is the maximum absorbance for most proteins (because of tryptophan, tyrosine, and phenylalanine; $n=3$ ). HPLC analyses of $\mathrm{HbA}$ and $\mathrm{HbF}$ during erythroid differentiation $(n=4)$. (C) Detection of extracellular NO levels with fluorescent indicator DAF-2 in erythroid progenitor cells at day 6 , during treatment with bradykinin $(n=3)$. Values are means $\left( \pm\right.$ SEM). ${ }^{*} P<.05$ and ${ }^{* \star} P<.01$ compared with cells at day 4 (B) and untreated with bradykinin (C).

mature RBCs compared with erythroid progenitor cells (data not shown). After 4 hours of incubation, hydroxyurea did not significantly inhibit cell growth by day 4 of erythroid cell culture, whereas hydroxyurea dose-dependently inhibited erythroid cells growth by $30 \%$ to $40 \%$ after 24 and 48 hours of incubation (Figure $3 \mathrm{~A})$. The effects of the 3 cytotoxic agents 5-azacytidine, hydroxyurea, and butyric acid on cell viability in the same erythroid cultures are already reported by our lab. ${ }^{19}$ Briefly, hydroxyurea (20-100 $\mu \mathrm{M})$ does not show a consistent and reproducible impact on cell number, whereas both 5-azacytidine (5-20 $\mu \mathrm{M})$ and butyric acid (0.1-1.0 $\mathrm{mM}$ ) addition resulted in reduced cell counts on the fourth day after adding erythropoietin to the cultured cells. 
A

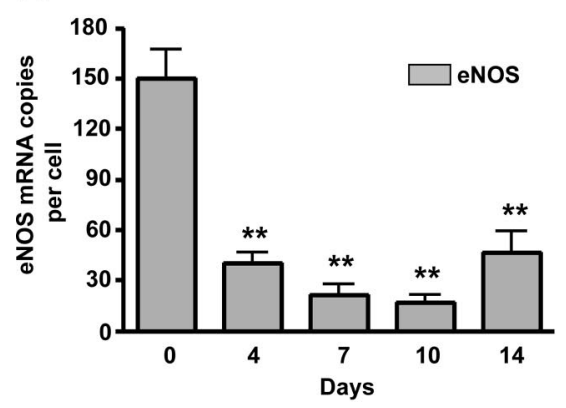

C

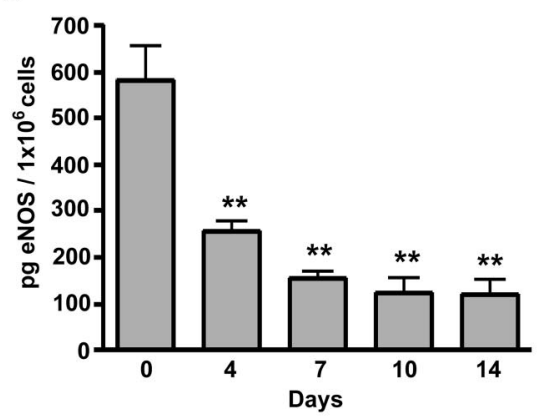

B

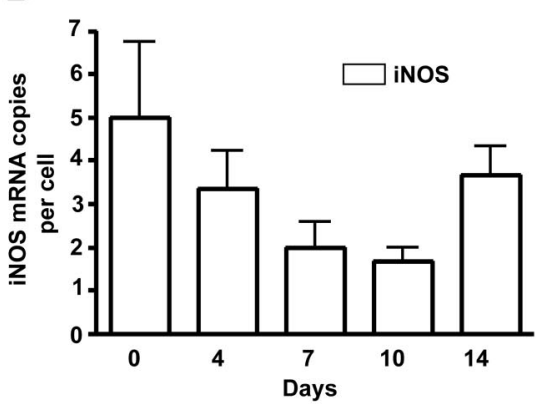

D
Figure 2. NOS levels during differentiation of erythroid cells. (A) eNOS mRNA levels during differentiation of erythroid cells. (B) iNOS mRNA levels during differentiation of erythroid cells; (C,D) eNOS protein levels during differentiation of erythroid cells: as measured by ELISA $(C)$ and Western blotting compared with actin protein levels as a control (D). Vertical lines have been inserted to indicate a repositioned gel lane $(n=3)$. Values are means $\left( \pm\right.$ SEM). ${ }^{\star \star} P<.01$ compared with cells at day 0 .

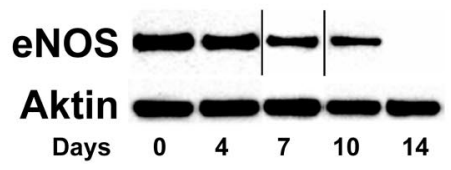

Hydroxyurea increased intracellular cGMP levels $\left(60-80 \mathrm{fmol} / 10^{5}\right.$ cells; Figure 3B) as well as cAMP levels (1000-1800 fmol/10 cells; Figure $3 \mathrm{C}$ ), thereby reducing the cGMP/cAMP ratio, in human erythroid progenitor cells after 4 hours of incubation. The NO donor, DEANONOate, induced much higher intracellular cGMP levels (600 fmol/10 $10^{5}$ cells, Figure 3B), but reduced cAMP levels (100-150 fmol/10 $10^{5}$ cells, Figure $\left.3 \mathrm{C}\right)$. The induced intracellular cGMP levels by hydroxyurea and DEANONOate, corresponded to the increase of extracellular cGMP levels of 30 to $50 \mathrm{fmol} / 10^{5}$ cells and 400 to $1600 \mathrm{fmol} / 10^{5}$ cells, respectively, after 2 hours of incubation.

\section{Induction of purified SGC by hydroxyurea and NO donors}

We hypothesized that hydroxyurea could also react with the ferrous heme group of sGC, resulting in iron-nitrosylation and enzymatic activation, in a way similar to the reaction of hydroxyurea and deoxyhemoglobin to form iron-nitrosyl-hemoglobin (HbNO). ${ }^{20}$ Using purified sGC in solution, we found by radioimmunoassay that $1 \mathrm{mM}$ hydroxyurea induced production of approximately $45 \mathrm{pM}$ cGMP/minute/ng sGC (average value for all presented quantities of sGC), similar to induction by $1 \mu \mathrm{M}$ of an NO donor, DEANONOate (Figure 4A,B). Also, we demonstrated dosedependent effects of hydroxyurea and the NO donor on cGMP production: $0.5 \mathrm{mM}$ hydroxyurea incubated with 10 and $50 \mathrm{ng}$ of sGC induces 29 and $12 \mathrm{pM}$ cGMP/minute/ng sGC, respectively, whereas $10 \mu \mathrm{M}$ DEANONOate induces 160 and $532 \mathrm{pM}$ cGMP/ minute/ng sGC, respectively (Figure 4A,B). Under the same conditions, without sGC, hydroxyurea $(0.001-100 \mathrm{mM})$ failed to create $\mathrm{NO}$ as measured via nitrite levels by NO analyzer (data not shown). Sodium nitrite $(0.001-10 \mathrm{mM})$ did not induce cGMP production of purified sGC as measured by radioimmunoassay (Figure 5A), which confirmed a primal role of NO (as a part of hydroxyurea molecule) in hydroxyurea induction of sGC.

In order to test for NO binding to the deoxy-heme of sGC, we measured the formation of the iron-nitrosyl complex with the modified tri-iodine-based chemiluminescence assay (with displace- ment of $\mathrm{NO}$ /thiol groups with $\mathrm{HgCl}_{2}$ ) following the induction of purified sGC by hydroxyurea. ${ }^{17} \mathrm{We}$ found that $10 \mathrm{mM}$ of hydroxyurea and $10 \mu \mathrm{M}$ ProliNONOate produced about $3 \mathrm{nM}$ and $30 \mathrm{nM}$ iron-nitrosyl levels per microgram of purified sGC, respectively (100 $\mathrm{mM}$ of hydroxyurea induces about $5 \mathrm{nM}$ iron-nitrosyl levels; Figure 5B). These data are consistent with earlier studies showing that hydroxyurea reacts with deoxyhemoglobin in vitro and converts $2 \%$ to $6 \%$ of the total hemoglobin to HbNO. ${ }^{20}$ In our studies, hydroxyurea reacted with deoxy-heme of sGC to convert $3 \%$ to $6 \%$ of the total heme to the iron-nitrosyl complex, whereas ProliNONOate converted $18 \%$ of the total heme of sGC to the same complex (Figure 5B). Therefore, we verified the hypothesis that hydroxyurea can directly interact with the deoxy-heme of sGC, generating the iron-nitrosyl complex, and consequently activate cGMP production.

\section{Discussion}

Human erythroid progenitor cells contain eNOS mRNA and protein and demonstrate eNOS activity. We observed a fall in eNOS mRNA and protein levels as well as its activity during erythroid differentiation, concomitantly with the elevation of hemoglobin levels. We found a continuous decrease in cAMP high levels in contrast to steady low levels of cGMP during erythroid differentiation. So, the eNOS protein level, as well as cAMP levels, continuously decline during erythroid differentiation. Their activity and presence is parallel to gamma-globin gene expression, which also declines during erythroid differentiation. Hydroxyurea, a drug which stimulates gamma-globin gene expression, increased steady intracellular cGMP levels as well as cAMP levels in human erythroid progenitor cells, whereas the NO donor increased intracellular cGMP levels but reduced cAMP levels. The cAMP signal is adjusted by cAMP degradation determined by phosphodiesterases 3 (PDE3) in erythroid cells, where the PDE3 is inhibited due to activation of $\mathrm{sGC}^{21}$ Using purified sGC we demonstrated that 

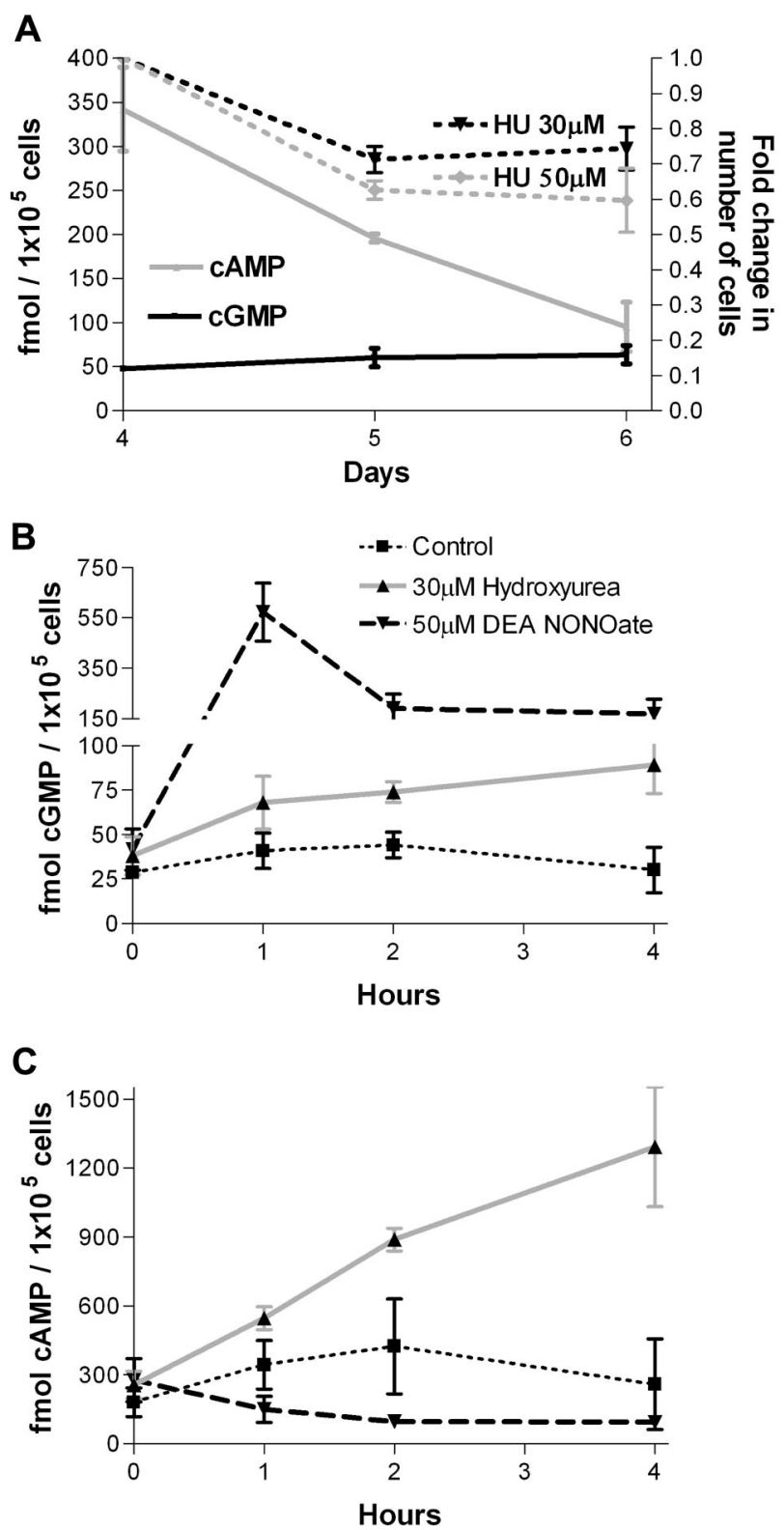

Figure 3. Intracellular cGMP and cAMP levels in human erythroid progenitor cells. (A) Intracellular cGMP and cAMP levels in erythroid progenitor cells (left $y$-axis). Hydroxyurea ( $H U)$ dose-dependently inhibits erythroid cells growth after 24 and 48 hours of incubation (right y-axis). (B) Hydroxyurea $(30 \mu \mathrm{M})$ and DEANONOate $(50 \mu \mathrm{M})$ increased cGMP levels during 4 hours of incubation of human erythroid progenitor cells at day 4 of phase II liquid culture. (C) Hydroxyurea (30 $\mu \mathrm{M})$ and DEANONOate $(50 \mu \mathrm{M})$ increases and inhibits, respectively, cAMP levels during 4 hours of incubation of human erythroid progenitor cells at day 4 of phase II liquid culture $(n=3)$. Values are means $( \pm$ SEM).

hydroxyurea could directly interact with deoxy-heme of sGC, generating the iron-nitrosyl complex, and consequently activating cGMP production. These results are all consistent with an NOdependent sGC mechanism for the elevation of $\mathrm{HbF}$ in erythroid progenitor cells.

It has been demonstrated that human RBCs contain iNOS and eNOS as well as calmodulin, suggesting that RBCs may synthesize their own NO. ${ }^{22}$ This notion was supported by the observation that RBCs have an active eNOS protein. ${ }^{23}$ However, it was later reported that RBCs possess iNOS and eNOS, but the proteins are without catalytic activity. ${ }^{24}$ Recent studies revealed eNOS protein in the cytoplasm and in the internal side of RBC

\section{A}

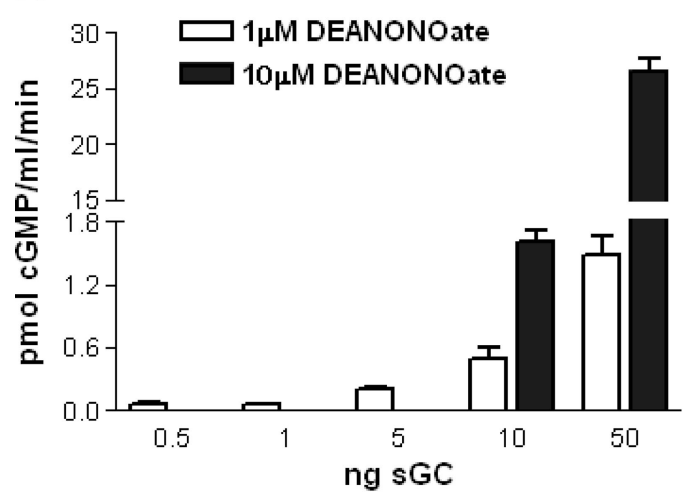

B

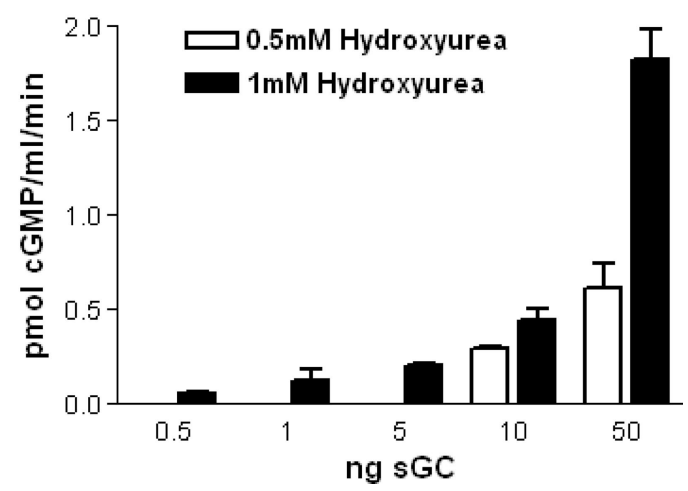

Figure 4. In vitro induction of purified SGC by hydroxyurea and NO donors. (A) Mixtures of purified sGC $(0.5,1,5,10$, and $50 \mathrm{ng}), 3 \mathrm{mM} \mathrm{MgCl}$, and $1 \mathrm{mM}$ GTP were treated with DEANONOate $(1$ and $10 \mu \mathrm{M})$ during 10 minutes of incubation. (B) Mixtures of purified sGC $(0.5,1,5,10$, and $50 \mathrm{ng}), 3 \mathrm{mM} \mathrm{MgCl}_{2}$ and $1 \mathrm{mM} \mathrm{GTP}$ were treated with hydroxyurea $(0.5$ and $1 \mathrm{mM})$ during 10 minutes of incubation. Background with 0 ng purified SGC, and the mixtures, was subtracted from the results $(n=3)$. Values are means \pm SEM

membranes as measured by activity. ${ }^{18}$ However, we demonstrated the continuous decline of eNOS presence and activity throughout erythroid differentiation, suggesting that such activity may be a residual of eNOS production at an earlier stage. Inhibition of NOS partially reversed the hydroxyurea effects on $\mathrm{HbF}$ synthesis in erythroid burst-forming unit (BFU-E) colonies, ${ }^{25}$ but did not decrease NOx production in RBCs during incubation with hydroxyurea. ${ }^{26}$ In contrast, NOS activity has been reported to be higher in RBCs of healthy individuals and patients with sickle cell disease on hydroxyurea therapy. ${ }^{27}$ This is in accordance with results that L-arginine increases serum NOx production only in combination with hydroxyurea in patients in steady state. ${ }^{28}$ It has been reported that hydroxyurea increases NO production in bone marrow endothelial cells. ${ }^{16}$ The paracrine effect of endothelial cell-derived NO on erythroid cells may be more physiologically relevant in sGC stimulation than hydroxyurea interaction with deoxy-heme of sGC.

Recent studies indicated that hydroxyurea increased $\mathrm{HbF}$ levels through the NO-dependent activation of sGC in erythroid cells. ${ }^{4}$ It has been shown that both sGC activators and cGMP induce gamma-globin gene expression in K562 erythroleukemia cells and primary erythroblasts, ${ }^{3}$ whereas the cAMP-dependent pathway plays a negative role in gamma-globin gene expression in K562 cells. ${ }^{29}$ Hydroxyurea increased cGMP levels in human erythroid progenitor cells, while gamma-globin induction by both hydroxyurea and NO donor was prevented by sGC inhibitors. ${ }^{4}$ cGMP levels correlated with $\mathrm{HbF}$ levels in hydroxy- 
A

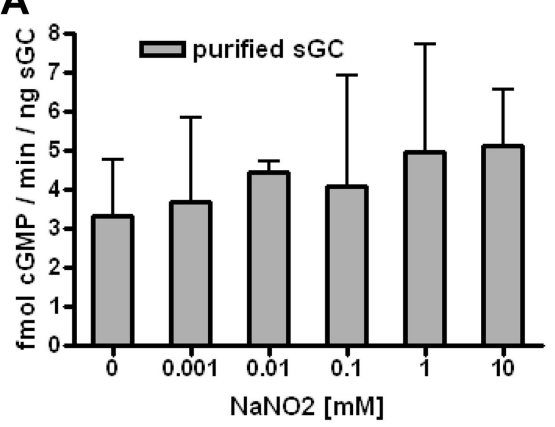

B

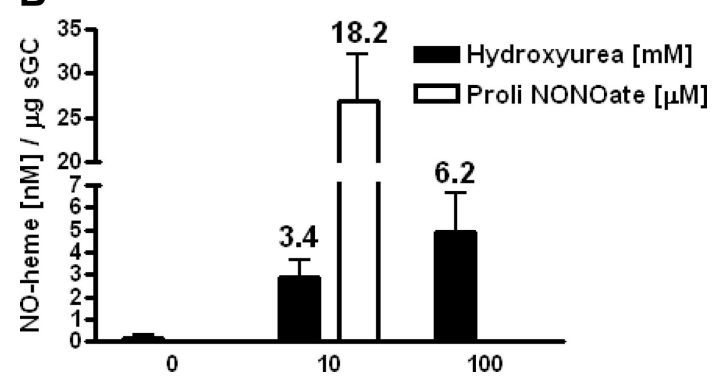

Figure 5. In vitro interaction between hydroxyurea and heme of sGC. (A) Sodium nitrite $(0.001-10 \mathrm{mM})$ did not induce cGMP production of purified SGC as measured by radioimmunoassay. (B) Using tri-iodine-based reductive chemiluminescence assay, we measured the formation of the iron-nitrosyl complex during treatment of purified sGC with hydroxyurea and ProliNONOate. The numbers above columns represent percentage of conversion of deoxy-heme to the iron-nitrosyl complex $(n=3)$. Values are means $( \pm$ SEM).

urea-treated patients with sickle cell disease. ${ }^{6}$ Hydroxyurea therapy also concomitantly increased NO, cGMP, and $\mathrm{HbF}$ levels in the same patients. ${ }^{5}$ During erythroid differentiation adenylate cyclase activity, cellular cAMP concentrations and cAMP phosphodiesterase activity have been reported to decline in a synchronized manner. ${ }^{30}$ In addition to our findings in this and a previous publication, ${ }^{4}$ there have been 2 reports of cAMP increasing $\mathrm{HbF}$ levels. Ikuta's group ${ }^{31}$ has reported that expression of the gamma-globin gene is induced upon activation of the cAMP pathway, while Dover and colleagues ${ }^{32}$ found that adenylate-cyclase inhibition markedly decreased $\mathrm{HbF}$ induction by hydroxyurea in human erythroid precursor cells. They also reported that hydroxyurea failed to significantly stimulate adenylate-cyclase activity, ${ }^{32}$ whereas we demonstrated that hydroxyurea stimulated cAMP production in erythroid progenitor cells. While our results are based on studies of erythroid progenitor cells, the above-mentioned studies ${ }^{31,32}$ are performed on erythroid precursor cells with lower cAMP and elevated hemoglobin levels, ${ }^{4}$ a potent NO scavenger. NO reduces cAMP levels in erythroid cells, whereas cAMP appears to enhance NO formation. ${ }^{33}$ The NO-mediated cAMP-reducing mechanisms may operate as a negative feedback in control of cAMP levels. Furthermore, the cGMP response to NO was higher in cells with elevated cAMP levels. ${ }^{34}$ As already revealed, the cAMPhydrolyzing PDE isozyme is a cGMP-inhibitable PDE3B in erythroid cells. ${ }^{29}$ Thus, the cAMP-dependent pathway can be simultaneously triggered since cGMP controls PDE3B activity. Therefore, it appears that hydroxyurea's parallel activation of the linked cGMP- and cAMP-regulatory pathways increases cyclic nucleotide related gamma-globin induction.

The reaction of $\mathrm{NO}$ with deoxyhemoglobin produces HbNO. ${ }^{35}$ Hydroxyurea initially oxidizes deoxyhemoglobin to methemoglobin and then reduces methemoglobin to deoxyhemoglobin during $\mathrm{HbNO}$ formation, progressing by inner-sphere mechanisms, where the NO group derives from the $-\mathrm{NHOH}$ portion of hydroxyurea. ${ }^{20,36} \mathrm{In}$ contrast, addition of $\mathrm{NO}$ to deoxyHbA quickly produces only $\mathrm{HbNO}$. It has been also observed that reaction products of hydroxyurea and deoxyHbA do not arise from the direct reaction of $\mathrm{NO} .{ }^{20} \mathrm{sGC}$ permits $\mathrm{NO}$ to bind directly to its ferrous deoxy-heme, activating the enzyme. ${ }^{37}$ Similar to the reaction of hydroxyurea and deoxyhemoglobin to form $\mathrm{HbNO}$, we demonstrate that hydroxyurea can also directly ironnitrosylate sGC and accordingly trigger cGMP production. Erythroid cells, as well as RBCs, contain high levels of sGC subunits representing an alternative locus for hydroxyurea interaction with deoxy-heme. ${ }^{3,38}$ It has been shown that nitrite ions increase blood flow in the human circulation as well as vasodilatation of rat aortic rings. Formation of both $\mathrm{NO}$ and NO-modified hemoglobin results from the nitrite reductase activity of deoxyhemoglobin. ${ }^{39}$ It has been also reported that deoxygenated myoglobin is an efficient nitrite reductase that generates bioavailable NO. ${ }^{40}$ Studies of nitrite activation of sGC demonstrated that nitrite alone (at concentration of $0.1 \mathrm{mM}$ ) moderately activated sGC in solution. ${ }^{41}$ In our in vitro studies nitrite failed to induce cGMP, in purified sGC in solution, confirming a major role of the NO molecule in hydroxyurea interaction with sGC. Moreover in a recent study, inorganic nitrite (in the range of $0.01 \mathrm{mM}-1 \mathrm{mM}$ ) also failed to increase sGC activity, but in combination with ascorbate increased sGC activity. ${ }^{42}$ A total of 2 distinct mechanisms have been proposed to explain in vitro nitrate activation of sGC: nitrate reacts with a $\mathrm{SGC}$ cysteine residue to yield NO or activation of sGC by an NO-independent mechanism. ${ }^{43}$

Our observations provide evidence for hydroxyurea stimulation of the NO/cGC pathway, as well as interaction between hydroxyurea and sGC. In addition to the possibility of some NOS presence and activity in mature RBCs, these data show strong eNOS protein levels and function in more primitive human erythroid progenitor and precursor cells, where control of gene expression occurs. The correlation between the levels of cyclic nucleotides and hydroxyurea induction illustrate their participation in hydroxyurea effects on erythroid and endothelial cells. Hydroxyurea stimulation of NO and cyclic nucleotide production may be involved in the therapeutic activity of hydroxyurea as both a cytostatic agent and a pharmacologic means to elevate fetal hemoglobin.

\section{Acknowledgments}

This research was supported by the Intramural Research Program of the NIH and NIDDK and by grant from the Serbian Ministry of Science and Environment (145048B).

\section{Authorship}

Contribution: V.P.C. designed and performed research, analyzed data, and wrote the paper. S.A.A. performed research and analyzed data. S.S.S. and C.T.N. analyzed data and wrote the paper. A.N.S. designed research, analyzed data, and wrote the paper.

Conflict-of-interest disclosure: The authors declare no competing financial interests.

Correspondence: Alan N. Schechter, Molecular Medicine Branch, NIDDK, NIH, 10 Center Dr, Bldg 10, Rm 9N307, Bethesda, MD 20892-1822; e-mail: aschecht@helix.nih.gov. 


\section{References}

1. Charache S, Terrin ML, Moore RD, et al. Effect of hydroxyurea on the frequency of painful crises in sickle cell anemia: investigators of the Multicenter Study of Hydroxyurea in Sickle Cell Anemia. N Engl J Med. 1995;332:1317-1322.

2. Atweh GF, Schechter AN. Pharmacologic induction of fetal hemoglobin: raising the therapeutic bar in sickle cell disease. Curr Opin Hematol. 2001;8:123-130.

3. Ikuta T, Ausenda S, Cappellini MD. Mechanism for fetal globin gene expression: role of the soluble guanylate cyclase-cGMP-dependent protein kinase pathway. Proc Natl Acad Sci U S A. 2001;98:1847-1852.

4. Cokic VP, Smith RD, Beleslin-Cokic BB, et al. Hydroxyurea induces fetal hemoglobin by the nitric oxide-dependent activation of soluble guanylyl cyclase. J Clin Invest. 2003;111:231-239.

5. Nahavandi M, Tavakkoli F, Wyche MQ, Perlin E, Winter WP, Castro O. Nitric oxide and cyclic GMP levels in sickle cell patients receiving hydroxyurea. Br J Haematol. 2002;119:855-857.

6. Conran N, Oresco-Santos C, Acosta HC, Fattori A, Saad ST, Costa FF. Increased soluble guanylate cyclase activity in the red blood cells of sickle cell patients. Br J Haematol. 2004;124:547-554.

7. Inoue A, Kuroyanagi Y, Terui K, Moi P, Ikuta T. Negative regulation of gamma-globin gene expression by cyclic AMP-dependent pathway in erythroid cells. Exp Hematol. 2004;32:244-253.

8. Krakoff IH, Brown NC, Reichard P. Inhibition of ribonucleoside diphosphate reductase by hydroxyurea. Cancer Res. 1968;28:1559-1565.

9. Yarbro JW. Mechanism of action of hydroxyurea. Semin Oncol. 1992;19:1-10.

10. Lassmann G, Thelander L, Graslund A. EPR stopped-flow studies of the reaction of the tyrosyl radical of protein $\mathrm{R} 2$ from ribonucleotide reductase with hydroxyurea. Biochem Biophys Res Commun. 1992;188:879-887.

11. Sakano K, Oikawa S, Hasegawa K, Kawanishi S. Hydroxyurea induces site-specific DNA damage via formation of hydrogen peroxide and nitric oxide. Jpn J Cancer Res. 2001;92:1166-1174.

12. Lepoivre M, Flaman JM, Bobe P, Lemaire G, Henry Y. Quenching of the tyrosyl free radical of ribonucleotide reductase by nitric oxide. Relationship to cytostasis induced in tumor cells by cytotoxic macrophages. J Biol Chem. 1994;269: 21891-21897.

13. Kwon NS, Stuehr DJ, Nathan CF. Inhibition of tumor cell ribonucleotide reductase by macrophage-derived nitric oxide. J Exp Med. 1991;174: 761-767.

14. Shami PJ, Moore JO, Gockerman JP, Hathorn JW, Misukonis MA, Weinberg JB. Nitric oxide modulation of the growth and differentiation of freshly isolated acute non-lymphocytic leukemia cells. Leuk Res. 1995;19:527-533.

15. Beleslin-Cokic BB, Cokic VP, Yu X, Weksler BB, Schechter AN, Noguchi CT. Erythropoietin and hypoxia stimulate erythropoietin receptor and nitric oxide production by endothelial cells. Blood. 2004; 104:2073-2080.

16. Cokic VP, Beleslin-Cokic BB, Tomic M, Stojilkovic SS, Noguchi CT, Schechter AN. Hydroxyurea induces the eNOS-cGMP pathway in endothelial cells. Blood. 2006;108:184-191.

17. Yang BK, Vivas EX, Reiter CD, Gladwin MT. Methodologies for the sensitive and specific measurement of S-nitrosothiols, iron-nitrosyls, and nitrite in biological samples. Free Radic Res. 2003;37:1-10.

18. Kleinbongard P, Schulz R, Rassaf T, et al. Red blood cells express a functional endothelial nitric oxide synthase. Blood. 2006;107:2943-2951.

19. Smith RD, Li J, Noguchi CT, Schechter AN. Quantitative PCR analysis of $\mathrm{HbF}$ inducers in primary human adult erythroid cells. Blood. 2000;95 863-869.

20. Huang J, Hadimani SB, Rupon JW, Ballas SK, Kim-Shapiro DB, King SB. Iron nitrosyl hemoglobin formation from the reactions of hemoglobin and hydroxyurea. Biochemistry. 2002;41:24662474.

21. Baumann R, Blass C, Götz R, Dragon S. Ontogeny of catecholamine and adenosine receptormediated cAMP signaling of embryonic red blood cells: role of cGMP-inhibited phosphodiesterase 3 and hemoglobin. Blood. 1999;15:94:4314-4320.

22. Jubelin BC, Gierman JL. Erythrocytes may synthesize their own nitric oxide. Am J Hypertens. 1996;9:1214-1219.

23. Chen LY, Mehta JL. Evidence for the presence of $\mathrm{L}$-arginine-nitric oxide pathway in human red blood cells: relevance in the effects of red blood cells on platelet function. J Cardiovasc Pharmacol. 1998;32:57-61.

24. Kang ES, Ford K, Grokulsky G, Wang YB, Chiang TM, Acchiardo SR. Normal circulating adult human red blood cells contain inactive NOS proteins. J Lab Clin Med. 2000;135:444-451.

25. Haynes J Jr, Baliga BS, Obiako B, Ofori-Acquah $\mathrm{S}$, Pace B. Zileuton induces hemoglobin $\mathrm{F}$ synthesis in erythroid progenitors: role of the L-arginine-nitric oxide signaling pathway. Blood. 2004; 103:3945-3950.

26. Nahavandi M, Tavakkoli F, Millis RM, Wyche MQ, Habib MJ, Tavakoli N. Effects of hydroxyurea and $\mathrm{L}$-arginine on the production of nitric oxide metabolites in cultures of normal and sickle erythrocytes. Hematology. 2006;11:291-294.

27. Iyamu EW, Cecil R, Parkin L, Woods G, OheneFrempong K, Asakura T. Modulation of erythrocyte arginase activity in sickle cell disease patients during hydroxyurea therapy. $\mathrm{Br} \mathrm{J}$ Haematol. 2005;131:389-394.

28. Morris CR, Vichinsky EP, van Warmerdam J, et al. Hydroxyurea and arginine therapy: impact on nitric oxide production in sickle cell disease. $\mathrm{J} \mathrm{Pe}$ diatr Hematol Oncol. 2003;25:629-634.

29. Inoue A, Kuroyanagi Y, Terui K, Moi P, Ikuta T.
Negative regulation of gamma-globin gene expression by cyclic AMP-dependent pathway in erythroid cells. Exp Hematol. 2004;32:244-253.

30. Setchenska MS, Arnstein HR, Vassileva-Popova JG. Cyclic AMP phosphodiesterase activity during differentiation of rabbit erythroid bone marrow cells. Biochem J. 1981;196:887-892.

31. Kuroyanagi $Y$, Kaneko $Y$, Muta K, et al. cAMP differentially regulates gamma-globin gene expression in erythroleukemic cells and primary erythroblasts through c-Myb expression. Biochem Biophys Res Commun. 2006;344:1038-1047.

32. Keefer JR, Schneidereith TA, Mays A, Purvis SH, Dover GJ, Smith KD. Role of cyclic nucleotides in fetal hemoglobin induction in cultured CD34+ cells. Exp Hematol. 2006;34:1151-1161.

33. Ferro A, Queen LR, Priest RM, et al. Activation of nitric oxide synthase by beta 2-adrenoceptors in human umbilical vein endothelium in vitro. $\mathrm{Br} \mathrm{J}$ Pharmacol. 1999;126:1872-1880.

34. Reiser G. Nitric oxide formation caused by $\mathrm{Ca}^{2+}$ release from internal stores in neuronal cell line is enhanced by cyclic AMP. Eur J Pharmacol. 1992; 227:89-93.

35. Sharma SV, Traylor TG, Gardiner R, Mizukami H. Reaction of nitric oxide with heme proteins and model compounds of hemoglobin. Biochemistry. 1987;26:3837-3843.

36. Kim-Shapiro DB, King SB, Shields H, Kolibash CP, Gravatt WL, Ballas SK. The reaction of deoxy-sickle cell hemoglobin with hydroxyurea. Biochim Biophys Acta. 1999;1428:381-387.

37. Denninger JW, Marletta MA. Guanylate cyclase and the .NO/cGMP signaling pathway. Biochim Biophys Acta. 1999;1411:334-350.

38. Petrov V, Lijnen P. Regulation of human erythrocyte $\mathrm{Na}^{+} / \mathrm{H}^{+}$exchange by soluble and particulate guanylate cyclase. Am J Physiol Cell Physiol. 1996;271:C1556-C1564.

39. Cosby K, Partovi KS, Crawford JH, et al. Nitrite reduction to nitric oxide by deoxyhemoglobin vasodilates the human circulation. Nat Med. 2003;9: 1498-1505.

40. Shiva S, Huang Z, Grubina R, et al. Deoxymyoglobin is a nitrite reductase that generates nitric oxide and regulates mitochondrial respiration. Circ Res. 2007;100:654-661

41. Jeffers A, Xu X, Huang KT, et al. Hemoglobin mediated nitrite activation of soluble guanylyl cyclase. Comp Biochem Physiol A Mol Integr Physiol. 2005;142:130-135.

42. Kollau A, Beretta M, Gorren AC, et al. Bioactivation of nitroglycerin by ascorbate. Mol Pharmacol. 2007;72:191-196.

43. Artz JD, Toader V, Zavorin SI, Bennett BM, Thatcher GR. In vitro activation of soluble guanylyl cyclase and nitric oxide release: a comparison of NO donors and NO mimetics. Biochemistry. 2001;7:40:9256-9264. 